\title{
Mire jó, és mire nem a személyi elvü kisebbségi autonómia?
}

Dobos Balázs: A személyi elvü kisebbségi autonómiák Közép-Kelet-Európában. Budapest: Kalligram, 2020. 247 oldal

Dobos Balázs több lezárt kutatással és néhány mérvadó, többnyire angol nyelven, tekintélyes folyóiratokban és gyüjteményes kötetekben közreadott publikációval a tarsolyában a személyi elvű kisebbségi autonómiák kérdésének általában, és azon belül a kisebbségi választások világa avatott kutatójának számít. Legutóbbi, magyar nyelven publikált kötetében arra vállalkozik, hogy korábbi kutatásainak az eredményeit latba vetve támpontokat kínáljon a nem területi autonómia fogalmát ködössé tevő, a fogalomhasználat gyakorlatát beárnyékoló terminológiai tisztázatlanság meghaladásához. Az erre irányuló kísérlet módszere - a kötet célmeghatározása szerint - empirikus és összehasonlító: öt posztszovjet térségbeli ország, Észtország, Horvátország, Magyarország, Szerbia és Szlovénia kisebbségpolitikai gyakorlatát veti össze a személyi elvü autonómia legfontosabb elemeként kezelt választott önkormányzati alakzatok jogszabályi kereteit, intézményes jellegzetességeit, müködési gyakorlatuk néhány konzekvenciáját elemezve. A kötet egészében véve egyszerre nyújt többet az így felfogott célnál, és marad adós az empirikus, illetve komparatív elemzés néhány fontos vonatkozásában.

Az empirikus és komparatív elemzésre helyezett hangsúly stratégiai jelentőségű a szerzői szándék szerint, Dobos Balázs ugyanis úgy ítéli meg, hogy az összehasonlítás központi elemét tekintve vitán felül álló, körültekintően kiválasztott esetek tudományos szempontból megalapozott módszerű összehasonlítása vezethet csak olyan eredményre, amely kiutat jelenthet abból az áldatlan állapotból, hogy a nem területi autonómia jelenségével foglalkozó, az utóbbi évtizedben látványosan terebélyesedő nemzetközi szakirodalomban nincs egyetértés sem a fogalom szemantikai tartalmát, sem az alája tartozó empirikus esetek körét illetően. Az empirikus-komparatív megközelítés szükségessége mellett szól Dobos Balázs szerint az a körülmény is, hogy az értelmezéssel kapcsolatos tisztázatlanságok lehetővé tették egyes állami szereplők számára, hogy bizonyos kisebbségpolitikai gyakorlatokat, illetve intézményes megoldásokat kulturálisautonómia-alakzatokként tüntessenek

* A szerző politológus, a Babeş-Bolyai Tudományegyetem Politikatudományi Intézetének oktatója. E-mail: levente.salat@ubbcluj.ro 
fel nagylelkü, a nemzetközi kisebbségvédelmi standardokat felülmúló kisebbségpolitikájuk bizonyítékaként, miközben az állítólagos autonómia intézményei valójában az érintett kisebbségek fölött gyakorolt ellenőrzés eszközei.

Az így felfogott célra való tekintettel Dobos Balázs az összehasonlításra szánt eseteket, illetve az összehasonlítás módszertanának központi elemét igen körültekintően választotta ki. Olyan térségre összpontosított mindenekelőtt, amelyet egyfelől a személyi elvű autonómia eredetvidékének tekint, ${ }^{1}$ másfelől, amely gazdag a kulturális autonómia létrehozására irányuló eszme- és politikatörténeti előzmények vonatkozásában. A térségen belül olyan eseteket választott ki, amelyekre nagyjából azonos módon voltak befolyással ,a posztkommunista átmenet politikai és gazdasági jellegzetességei”. ${ }^{2}$ Az összehasonlítás instrumentumának a tekintetében pedig a személyi elvű autonómia legkarakterisztikusabb elemre, a tanácsokat, kisebbségi önkormányzatokat eredményező választások mozzanata emellett döntött, amelyek közjogi formában vannak jelen mind az öt kiválasztott állam esetében.

Miközben ezek az opciók vitathatatlanul a munka egészének a szilárd elméleti és módszertani megalapozottságára utaló bizonyítékokként foghatók fel, nem lehet eltekinteni attól, amint az a komparatív elemzések esetében általában lenni szokott, hogy a tárgy és a módszer elhatárolásával kapcsolatos döntések árával is számolnia kell a szerzőnek. A regionális fókusz mellett például, miként az az alábbiakból is kiderül, jól exponált, meggyőző érvek szólnak, ennek ellenére nem lehet kitérni a kérdés elől, hogy van-e alapja annak az elvárásnak, hogy egy régióra leszükített empirikus vizsgálat konklúziói támpontokat kínáljanak egy, a világ számos térségében ismert jelenségre utaló fogalom jelentésével, normatív tartalmával kapcsolatos viták eldöntésében. A közjogiság aspektusára helyezett hangsúly pedig, miközben valóban megteremti az értelmes összehasonlítás lehetőségét, és kellő alapot biztosít a személyi elvű autonómiaalakzatok intézményes konzekvenciáinak az elmélyültebb átgondolásához, arra kárhoztatja a müvet, hogy olyan esetekre összpontosítson, amelyek igen csekély számú tagsággal rendelkező közösségek helyzetének a rendezését hivatottak biztosítani: olyanokéra, amelyek elhanyagolható etnopolitikai téttel bíró kihívást jelentenek azoknak az államoknak, amelyek területén élnek, miközben a világ számos térségében - Közép- és Dél-Amerikában, Nyugat-Európában, a Közel-Keleten, Közép- és Délkelet-Ázsiában, az arab világban, Ausztrália és Új-Zéland térségében stb. - számos további példa létezik arra,

1 ,a személyi elvű kisebbségi autonómia gondolata [...] jelentős mértékben közép-európainak mondható". 11. Ebben a tekintetben szükségesnek látszik megjegyezni, hogy Dobos Balázs fogalomhasználata, illetve maga a kötet címe is kisebb korrekcióra szorul: tekintettel arra, hogy sem a Baltikum, sem a Nyugat-Balkán nem tekinthető Közép-Európa részének, célszerübb lett volna, talán, a 'Köztes-Európa' kifejezést használni. Ugyanakkor a vizsgálat céljának megfelelően körülhatárolt térségről valóban nem alaptalan azt állítani, hogy az a személyi elvü kulturális autonómia eredetvidéke, hiszen, mint látni fogjuk, mind a Baltikumban, mind Közép-Európában, mind az egykori Jugoszláviában voltak „elöképei” a kulturális autonómiának.

279. 
hogy a Dobos Balázs által vizsgált kisebbségeknél lényegesen népesebb etnokulturális közösségek vonatkozásában a de facto - és ritkábban, de az is előfordul, hogy intézményesített - jogi pluralizmus által tolerált tanácsok és egyéb testületek látnak el fontos funkciókat, ahhoz foghatókat, amelyekre Dobos Balázs vizsgálata irányul. A posztkommunista átmenet által biztosított politikatörténeti háttér kritériumként való kezeléséből pedig az következik Dobos Balázs számára, hogy a térséghez tartozó, választott testületekként Norvégiában, Svédországban és Finnországban müködő számi parlamenteket ki kell zárnia a vizsgált esetek köréből.

A könyv bevezetőjében beharangozott empirikus-komparatív fókusznak némiképp ellentmond, hogy az olvasónak meglehetősen hosszú, a kötet bő harmadát kitevő elméleti, fogalomtörténeti részen kell átrágnia magát, amíg eljut a szerző által deklarált célt kibontó részéhez a munkának. A lényegnek ez a késleltetése azonban közel sem eredményez redundanciát. Ellenkezőleg: e sorok szerzőjének a megítélése szerint a kötet legértékesebb része az a három alfejezet, amelyek a szerző által „előképeknek” nevezett, a személyi elvü kisebbségi autonómia eszme- és politikatörténeti előzményeibe engednek bepillantást egyfelől, illetve azokat a további térségbeli eseteit tekintik át a személyi elvű kisebbségi autonómiának, amelyek a választott módszer következtében nem kerültek be az összehasonlításra kiválasztott esetek körébe. Olyan részletekre derül fény ezekben az alfejezetekben, amelyek a személyi elvủ autonómiák nemzetközi irodalmában tájékozott olvasó számára is érdekesek, újak, tanulságosak lehetnek.

Szóba kerül többek között a személyi elvű autonómia és az egyházak mint intézmények közötti analógia kérdése, amelyet a szakirodalom nem tárgyal érdemben (a sürün emlegetett oszmán milletrendszerre történő hivatkozások, amint erre Dobos Balázs is rávilágít, a korabeli hatalomszervezési technikák szempontjából érdekesek csupán, a kérdés jogi-intézményi vonatkozásai nem relevánsak a személyi elvü autonómia jelenségére nézvést). Külön érdekes Dobos megközelítésében, hogy Rennernek a területi alap nélkül elképzelhetetlen állam és a személyi elv alapján szerveződő, területi jelleggel nem mindig rendelkező nemzet közötti különbségtételre vonatkozó javaslatát rokoníthatónak gondolja azzal az állásponttal, amelyet Eötvös József az 1865-ös, A nemzetiségi kérdés címủ mủvében ${ }^{3}$ fejt ki a vallási és a nemzeti mozgalom közötti analógiát illetően. Noha az Eötvöst foglalkoztató kérdésekben valóban fontos a személyi elvre helyezett hangsúly a területiséggel szemben, a hivatkozott mü figyelmes olvasata alapján látni lehet, hogy az Eötvös által többször emlegetett analógia kimerül abban, hogy az állam és a nemzeti mozgalmak viszonyát ahhoz hasonlóan kell kezelni, ahogy az egyház és az állam korábban konfliktusokat eredményező viszonyát sikerült nyugvópontra juttatni egyfelől az állam és az egyház szétválasztása, másfelől a vallásos identitás

3 Báró Eötvös József: A nemzetiségi kérdés. Budapest: Ráth Mór Kiadása, 1865. Elektronikus változat: Budapest: Magyar Elektronikus Könyvtárért Egyesület, 2010. 
megválasztásának a törvény által biztosított szabadsága révén. ${ }^{4}$ Ennél tovább Eötvös nem megy - a nyelvi jogok vonatkozásában is csak az egyesületi élet lehetőségét említi a törvényhozásbeli szabad nyelvhasználat mellett ${ }^{5}$ - ami azt jelenti, hogy álláspontja nem érinti az egyháznak mint intézménynek azokat az aspektusait, amelyek a kulturális autonómia szervezeti sajátosságai szempontjából analógiaként fontosak lehetnének.

Dobos Balázs említi ugyan: Renner elméletének alakulásában szerepe volt annak, hogy az Ausztriai Szociáldemokrata Párt 1899-es brünni kongresszusán a szlovén küldöttek a katolikus egyház „mintájára” létrehozott kulturális autonómiát szorgalmaztak a Monarchia-beli népcsoportok számára a garast a területi elv mellett letevő csehekkel szemben, de további részleteket erről a fontos mozzanatról nem oszt meg az olvasóval. Kár, mert az egyházak és a személyi elvü autonómiaalakzatok közötti párhuzamból következő konzekvenciák alaposabb végiggondolása bővíthetné a felsorakoztatható érvek tárházát azokkal az államokkal szemben, amelyek elzárkóznak a személyi elvü autonómiaigények elöl, azt hangoztatva, hogy területükön az autonómia semmilyen intézményes formája nem képzelhető el, holott állam által elismert egyházak mindenhol vannak.

Rendkívül izgalmas a könyvnek az a része, amely a személyi elvű autonómia eszme- illetve eredettörténetének zsidó és német gyökereibe enged bepillantást. Kiderül például a Dobos által használt forrásokból, hogy a cári Oroszország zsidóságának a személyi elvű autonómiához füződő, a cionizmussal szembemenő elképzelései nem írhatók kizárólag az ausztromarxizmus befolyásának a számlájára, hanem azoknak Renner és Bauer nézeteinek hatásánál lényegesen mélyebbre nyúló és szervesebb gyökerei vannak az északkelet-európai térségben.

Létezett például egy Négy Ország Tanácsa nevü önigazgatási testület, amely az 1500-as évek második felével kezdődően előbb adószedési, majd később adminisztratív, törvényhozó, bíráskodási és kulturális feladatokat látott el négy korabeli államalakulat, Nagy- és Kis-Lengyelország, Volhínia és Ruténia zsidóságának a vonatkozásában. Ebből a testületből később kiléptek a litvániai zsidók, és saját tanácsot hoztak létre. Zsidó önkormányzati testületek müködtek továbbá a Lengyel-Litván Unió fennállása alatt, egészen a 18. század közepéig. Ezeket a hagyományokat próbálta felébreszteni az oroszországi zsidóság néppárti irányzata Simon Dubnow történész és politikus szellemi vezetése alatt, aki az 1905-ös eseményeket követően alapított Zsidó Néppárt keretei között helyi szinten szervezett autonóm

4 ,... a kérdésnek eldöntésében, mily felekezethez tartozzék minden egyes, csak az egyeseknek lelkiismérete határozhat s hogy minden vallásnak fenntartása és terjesztése az egyesek buzgóságára bízandó, a törvények egyedüli feladása az maradván, hogy mindenkit szabadsága élvezetében megoltalmazzon...", I. m., 58.

5 „Minden egyes szabadon buzoghat nemzetisége mellett, saját nyelvének mivelésére és terjesztésére az egyesületi tért kisértheti meg, s ha a törvényhozásnál saját nyelvén szólni akar, ezt szabadon teheti." I. m., 62. 
zsidó tanácsok létrehozatalát látta volna célszerünek egy átfogó, demokratikusan megválasztott zsidó nemzeti tanács ernyője alatt. Az 1887-ben, Vilniusban alapított Általános Zsidó Munkásszövetség, a Bund követelései között az alapítás pillanatától szerepelt az autonómia, 1903-tól pedig a hivatalos pártprogram részét képezte az az elképzelés, hogy személyi elven létrejövő önkormányzati testületekre kellene bízni a zsidó kulturális ügyek intézését, egy idő után pedig minden oroszországi nemzetiség számára autonómiát követeltek. Moshe Zilberfarb, a Szocialista Zsidó Munkáspárt teoretikusa Oroszországot a nemzetiségek föderációjaként képzelte el, abban a formában, hogy minden nemzetiség megválasztaná a maga nemzeti gyülését. Utóbb Ukrajnában, a függetlenség kikiáltását követően Zilberfarb a Nemzeti Ügyek Általános Titkárságán a zsidó ügyek felelőse lett, e minőségében elkészítette a személyi elvű autonómiáról szóló törvény tervezetét, amelyet 1918-ban fogadott el az Ukrán Központi Rada a kulturális autonómia történetében az első törvényerőre emelt elképzelésként. A szovjet hatalomátvételt követően az alkalmazásra azonban már nem kerülhetett sor. Érdekes adalék továbbá, hogy a párizsi békekonferencián a lengyel, litván, délszláv, ukrán, csehszlovák és román területekről érkező zsidó küldöttek azt szerették volna elérni, hogy a kisebbségi szerződések az említett területek zsidósága számára kulturális autonómiát biztosítsanak, a törekvés azonban nem érte el a célját.

A két világháború között a kelet- és közép-európai térség legnagyobb lélekszámú kisebbsége, a németek körében is népszerü volt a kulturális autonómia gondolata, egyfelől a Nemzetek Szövetségének a kisebbségvédelmi rendszerével kapcsolatban érzett fenntartások, másrészt Renner és Bauer nézeteinek a német kisebbségek vezetőire gyakorolt hatása okán, különösképpen a Baltikumban. Három érdekes vonatkozása van ennek a történetnek a Dobos Balázs által közreadott összefoglaló szerint.

Az egyik a személyi elvü autonómia elgondolásában rejlő lehetőségek fölfedezése és az azok gyakorlatba ültetését célzó, kitartó erőfeszítések a német kisebbség több vezetője részéről: Ewald Ammende és Werner Haselblatt részt vettek az észt kulturálisautonómia-törvény kidolgozásában, Paul Schiemann pedig a mai Lettország területén fejtett ki intenzív tevékenységet a személyi autonómia intézményében rejlö lehetőségek népszerüsítésében.

Schiemann és Ammende (más német kisebbségi politikusokkal, többek között az erdélyi szász Rudolf Brandsch-sal együtt) részt vettek ugyanakkor az 1922-ben alapított Európai Német Népcsoportok Szövetségének a szervezésében, amelynek központi célja, kezdetben legalábbis, a kulturális autonómia elérése volt. A szervezet által kifejtett széles körü lobbitevékenységnek egyik fontos célkitűzése lett egy idő után a Német Birodalom kormányának meggyőzése arról, hogy a Birodalom határain kívülre szakadt német kisebbségek érdekében kifejtett politika csak akkor lehet sikeres, ha a német kormány a saját nemzetiségeivel szemben nagylelkü kisebbségpolitikát folytat, aminek a kulturális autonómia lehet az eszköze. Ez a törekvés elérte 
a célját abban a formában, hogy Stresemann külügyminiszter valóban felkarolta a Baltikumban és a Duna menti országokban élő német kisebbségek ügyét, és támogatta kulturálisautonómia-törekvéseiket, miközben a németországi kisebbségek kulturális autonómiájának a törvénybe iktatását célzó erőfeszítései sikertelenek maradtak. Az 1930-as években az Európai Német Népcsoportok Szövetségének Berlinben székelö főtitkára Haselblatt lett, akinek a vezetése alatt a szervezet a kulturális autonómia ügyét egyre inkább a német nemzet határokon átnyúló kiterjesztéseként fogta fel. Többek között ennek a számlájára is írható, hogy a kulturális autonómiát Európában egyre többen kezdték a weimari Németország külpolitikájának az eszközeként megítélni, aminek nagy szerepe volt abban, hogy a személyi elvü autonómia mint széles körben alkalmazható megoldás fokozatosan lekerült az európai kisebbségpolitika napirendjéröl.

A harmadik érdekes vonatkozása a történetnek az Európai Nemzetiségek Kongresszusa, amelynek előkészítésében és megszervezésében Haselblatt és Ammende is fontos szerepet játszott. Az első ízben 1925 októberében megszervezett, 1938 augusztusáig 14-szer összehívott kongresszus története drámai, de rendkívül tanulságos dokumentumgyüjteményt eredményezett az európai kisebbségvédelem egy fontos fejezetét illetően, amelyről sajnálatosan kevés szó esik manapság (leginkább annak betudhatóan, hogy 1937-tel kezdődőleg a kongresszus munkájában a nemzetiszocialista irányultságú képviselők váltak hangadókká). A kongresszus eredetileg - a különböző európai kisebbségek államok feletti együttmüködésének a szorgalmazása, illetve lehetővé tétele mellett - a kulturális autonómia koncepciójában határozta meg hosszú távú stratégiai célját, ennélfogva kifogásolható, hogy Dobos Balázs nem látta elég fontosnak - a számos egyéb izgalmas politikatörténeti kalandozás mellett - ismertetni azokat a problémákat, amelyekkel a kongresszus kezdeményezői, köztük Ammende leginkább, a kulturális autonómia elfogadtatására irányuló erőfeszítései során szemben találták magukat. Érdekes adalék, hogy miközben Eiler Ferenc három egyéb, a tárggyal kapcsolatos munkájára hivatkozik Dobos Balázs, a kongresszus határozatainak 1996-ban Szegeden, a Documenta Historica sorozatban megjelent, Eiler Ferenc által magyarra fordított, sajtó alá rendezett és eligazító bevezetővel ellátott gyüjteménye ${ }^{6}$ feltehetőleg elkerülte az egyébként alaposan tájékozódó szerző figyelmét.

Fölöttébb hasznos leltár hámozható ki a könyvből arra nézvést is, hogy hol, mikor és milyen tartalommal történt kísérlet arra a Dobos Balázs által vizsgált térségben, hogy a személyi elv, illetve a kulturális autonómia elgondolása alkalmazásra kerüljön a gyakorlatban. Renner 1899-ben álnéven (Rudolf Springer: Staat und Nation) megjelent munkájával hozható feltehetően összefüggésbe az 1905-ös morvaországi kompromisszum (egyéb fontos, a tartomány német és cseh nyelvű

6 Európai Nemzeti Kisebbségek Kongresszusainak határozatai (1925-1937). Fordította és sajtó alá rendezte: Eiler Ferenc. Szeged: A JATE Történész Diákkör kiadványa, 1996. 
közösségei közötti vitás kérdések rendezése mellett a tartományi diéta küldötteinek a megválasztásakor a szavazókat cseh és német nyelvi identitásuk szerint osztották külön választási körzetekbe); külön szavazói jegyzékeket hoztak létre 1909ben Bukovinában a helyi román, ruszin, lengyel, német és zsidó népesség számára (az utóbbiak esetében nem volt hatálya a rendelkezésnek Bécs vétója miatt); az 1910-ben annektált Bosznia-Hercegovinában az oktrojált alkotmány a pravoszláv, muszlim, római katolikus és zsidó közösségek számára önkormányzatot biztosított kulturális és vallási tekintetben, a választásokat pedig vallási alapon felosztott körzetekben szervezték meg. 1914-ben jött létre a galíciai kompromisszum, amely a tartomány lengyel és ukrán-ruszin közösségeinek a tekintetében alkalmazott volna hasonló megoldást, amelynek kivitelezésére azonban már nem kerülhetett sor a háború kitörése folytán, akárcsak a České Budějovice-i (Budweis) megállapodás vonatkozásában a helyi csehek és németek között.

Számos olyan esetre utal a könyv, amelyben kulturális autonómia-törvényt fogadtak el, fölmerült annak szükségessége, illetve az elfogadott törvény ideig-óráig alkalmazásra is került. A már említett, 1918-ban a rövid életü független Ukrajnában elfogadott személyi elvü autonómiáról szóló, alkalmazásra végül nem került törvény mind előkészítése, mind elfogadása, illetve a személyi elvű autonómiát kompromisszumok nélkül tükröző tartalma folytán is figyelmet érdemel. Litvániában 1920-ban fogadtak el törvényt a zsidó kulturális autonómiáról: a törvény közjogilag ismerte el a települési szinten hagyományosan müködö választott zsidó tanácsokat. Hasonló volt a helyzet Lettországban is, tudjuk meg Dobos Balázstól, ám további részletek nem derülnek ki az ott érvényes törvény elfogadásának időpontjáról. 1925-ben fogadták el az észt kisebbségi törvényt, a kulturális autonómia történetének legtöbbet hivatkozott dokumentumát, amely lehetővé tette, hogy a német és a zsidó kisebbségek megválasszák saját kisebbségi tanácsaikat (a törvény által biztosított lehetőséggel a svéd és az orosz kisebbségek nem kívántak élni arról, hogy miért nem, illetve a törvény elfogadásának a folyamatáról, továbbá az alkalmazás történetéről izgalmas részletek derülnek ki Dobos Balázs könyvéből). A modell mint lehetséges megoldás fölmerült az 1920-as évek második felében a karintiai szlovének vonatkozásában, majd az 1930-as években Csehszlovákiában, a szudétanémetek helyzetének rendezésére irányuló elképzelésként. Rövid időre megfeledkezve a maga számára kijelölt regionális fókuszról, Dobos Balázs megemlíti, hogy népszövetségi keretek között az 1920-as években fölmerült a személyi elvü autonómia elvének az alkalmazása Kanadában is, az őslakosok, a Québec tartományban élő angol anyanyelvü, illetve Kanada egyéb térségeiben élő francia ajkú lakosoknak a vonatkozásában.

Az „előképek” külön kategóriájaként említi Dobos Balázs az egykori Jugoszlávia területén foganatosított különutas megoldásokat, amelyek a második világháború után a Szovjetunió érdekövezetébe került más országok gyakorlatához képest a nemzetiségi kérdésben nem követték a kommunista tanok útmutatásait, hanem 
többnyire tagköztársasági hatáskörben - amit egy 1959-es szövetségi szintü nemzetiségpolitikai párthatározatot erősített meg egy idő után - kisebbségi kulturális szervezetek létrejöttét és müködtetését tették lehetővé, többek között választott nemzetiségi bizottságokét is. Ezeknek a történetét Dobos Balázs főként a magyar kisebbséghez kötődő példák révén göngyölíti fel, megemlítve az 1949-ben létrejött Horvátországi Magyar Kultúr- és Oktatási Szövetséget, az 1960-ban a muraszombati járásban létrehozott nemzetiségi bizottságot, illetve az 1974-es szlovén köztársasági alkotmány elfogadását követően választott magyar (és olasz) nemzetiségi testületeket, amelyeket a kulturális autonómia fogalomköréhez hasonló kompetenciákkal ruházott fel az alkotmány szövege.

Az eszme- és politikatörténeti előzmények újabb fejezetét képezi a hidegháború végét követően a vizsgált térségben foganatosított kisebbségvédelmi megoldások sora, amelyeket Dobos Balázs a választott testületeket nélkülözö, ,egyesületi-funkcionális modell" alapján múködő autonómiáknak nevez, jelezvén mindazonáltal, hogy ezeknek a berendezkedéseknek az esetében az autonómia érvényesülése vitatható. Ezek között a példák között kerül említésre a Litvániában 1989-ben elfogadott, 1991-ben további rendelkezésekkel kiegészített törvény az etnikai kisebbségekről, amely lehetővé teszi a kisebbségek által létrehozott kulturális szervezetek számára, hogy a kulturális autonómia fogalomkörébe tartozó kompetenciákat gyakoroljanak. Lettországban a litván példához hasonlóan 1991-ben, a függetlenség kikiáltását megelőzően fogadtak el egy kisebbségi törvényt, amely a címében is utal a kulturális autonómiára. Ukrajnában 1992-ben került elfogadásra a nemzeti kisebbségekről szóló törvény, amely explicite deklarálja a nemzeti-kulturális autonómiához való jogot. Csehországban a 2001-ben elfogadott, a nemzeti kisebbségek jogairól rendelkező törvény nemzeti bizottságok létrehozatalát teszi lehetővé, a megyei önkormányzatok tanácsadó testületeként.

Oroszországban 1996-ban fogadtak el törvényt a nemzeti kulturális autonómiáról, amely azokat a nemzeti közösségeket hivatott szolgálni, amelyek nem haszonélvezői a lenini-sztálini nemzetiségpolitika örökségeként érvényben maradt területi alapú rendezésnek, a tituláris nemzetiségek aszimmetrikus föderatív rendszerének, illetve a területi autonómia néhány további formájának. A törvény három - helyi, regionális és szövetségi - szinten létrehozható kisebbségi szervezeteket ruház föl, többnyire deklaratív módon, autonóm jogkörökkel. Noha a törvény számos vitára ad okot, többek között a kisebbségi szervezetek jogállásának, hatásköreinek, reprezentativitásának és finanszírozásának a kérdésében, 2020 tavaszáig 23 nemzeti kisebbség - német, zsidó, ukrán, tatár, belarusz, lezg, kurd, roma, örmény, azeri, csuvas, karacsáj, lengyel, koreai, litván, asszír, kazah, görög, szerb, nogaj, mari, grúz és moldáv - hozott lére szövetségi szintü kulturális autonómiát.

„Köztes” autonómiaalakzatokként említi a szerző a 2006-ban elfogadott montenegrói törvény által elismert nemzetiségi tanácsokat, a szlovéniai Roma Tanácsot, illetve az ukrajnai Kurultájt, amelyek közös vonása, hogy részben választott, 
részben delegált tagokból álló testületek. A montenegrói nemzeti tanácsok négyéves ciklusok keretében részlegesen választott testületek, abban az értelemben, hogy az elektori gyülések által megválasztott tagok mellett a kisebbségi parlamenti képviselők, a kisebbségi pártok vezetői és a kisebbségeket képviselő megválasztott polgármesterek hivatalból delegált tagjai a tanácsoknak. A 2013-ban, második alkalommal tartott választások alkalmával a roma, szerb, horvát, muszlim, bosnyák és albán kisebbségek tudták teljesíteni a törvény elöírásait és választottak maguknak kisebbségi tanácsokat. A szlovéniai Roma Tanács a 2007-ben elfogadott, a roma közösségről szóló törvény elöírásainak megfelelően jött létre még ugyanabban az évben. A 21 tagú testület 14 tagját egy roma egyesületeket tömörítő ernyőszervezet delegálja, a maradék hét tagot választják. Az ukrajnai Kurultáj a krími tatárok nemzeti kongresszusa, amelyet 1917-ben választottak meg első ízben. Az 1991-ben, még Ukrajna függetlenségének visszanyerése előtt újból megválasztott 200 tagú testület bonyolult választási procedúra eredménye, utóbb különböző tatár szervezetek által delegált további 50 taggal egészült ki. A Kurultáj munkáját a helyi és regionális szinten megszervezett, Medzslisznek nevezett végrehajtó testületek segítik, amelyeket egy 2008-as határozatot követően titkos és közvetlen választások keretében választanak meg. A Dobos Balázs által hivatkozott források szerint 2010-ben 200 helyi szintü és 23 regionális medzslisz létezett Ukrajnában. Azok a részletek, amelyeket a montenegrói, szlovéniai roma és krími tatár példák összefüggésében oszt meg olvasóival a szerző a törvényes rendelkezések részleteit, azok időbeni alakulását, illetve az alkalmazás tapasztalatait és következményeit illetően, rendkívül érdekesek és tanulságosak.

A fentiekben kiemelt példák alapján nem túlzás azt a következtetést levonni, hogy a térségben a személyi elv alapján álló megoldások, amelyek a domináns többségek és a különböző etnokulturális kisebbségek viszonyát próbálták vagy voltak hivatottak rendezni, lényegesen szélesebb körben vannak jelen mind a közelmúlt történelmében, mind napjaink gyakorlatában, mint ahogy az a közfelfogásban tükröződik. A Renner és Bauer elméletével nagy valószínüséggel összefüggésbe hozható példák mellett számolni kell azokkal a gyakorlatokkal is, amelyeknek a történelemben meglehetősen mélyre nyúló gyökereik vannak, többek között abban a formában, hogy a középkorra jellemző jogi pluralizmus továbbélő örökségét lehet felfedezni bennük, mint például az egyházi jog- és intézményi gyakorlatban vagy a zsidó tanácsok önkormányzati hagyományaiban. ${ }^{7}$ A Dobos Balázs által feldolgozott és közkinccsé tett kazuisztika megérdemelt volna egy módszeresebb leltárt, amelyben az esetek időrendi sorrendben, nagyjából azonos szerkezetű leírás keretében kerültek volna bemutatásra.

7 További példaként említhető az egyes roma közösségek által napjainkban is éltetett közösségi törvénykezés, a Kris gyakorlata, lásd erről: Salat, L. - S. Mişcoiu: „Roma autonomous lawmaking - the Romanian case.” In: Malloy, H. T. - Salat, L. (eds.): Non-Territorial Autonomy and Decentralization. Ethno-cultural Diversity Governance. Routledge: 2021, 167-194. 
Amennyiben Dobos Balázs vállalkozott volna az általa feldolgozott forrásokból leszürt információk ilyen értelmű hasznosítására, minden bizonnyal eredményesebben oldotta volna meg azt a feladatot is, amelyet e sorok írója szerint csak mérsékelt sikerrel teljesített az „Elméleti keretek” című első alfejezetben, amely a személyi elvű kisebbségi autonómia fogalmának, illetve az ezzel kapcsolatos elméleti megfontolásoknak a kusza világában próbál rendet rakni. A különböző szerzők által képviselt álláspontok felsorakoztatása mellett ez az alfejezet történelmi példákra, elózményekre kénytelen hivatkozni, olyanokra, amelyekről az olvasó a könyv későbbi fejezeteiből tud meg további, lényeges részleteket. Az elméleti-fogalmi összefoglaló adós marad ugyanakkor egy megfelelően határozott szerzői konklúzióval azt illetően, hogy mi jelentheti a kiutat abból az ellentmondás-göngyölegböl, amely a nem területi, személyi elvủ autonómia kérdéskörével foglalkozó szakirodalmat jellemzi ez idő szerint. Amennyiben a kötet a fentebb kiemelt példák és előzmények célratöröbben összefoglalt ismertetésével kezdődött volna, valószínűsíthető, hogy a fogalmi-elméleti tisztázás feladatát is eredményesebben sikerült volna megoldania a szerzőnek. A könyv szerkezetével kapcsolatosan megfogalmazható továbbá az a kritika is, hogy a nemzetközi joggal foglalkozó, egyébként jól megírt alfejezet indokolatlanul szakítja meg az „előképek” bemutatásának a sorozatát.

A kötet tulajdonképpeni célját kivitelező empirikus rész, az öt - észt-, horvát-, magyarországi, szerbiai és szlovéniai - választott önkormányzati, tanácsi rendszer összehasonlító elemzése alapos, figyelmes munka. A többnyire másodlagos adatelemzésre és kisebb mértékben a szerző által készített interjúkra alapozott összehasonlítás eligazító módon tárja az olvasó elé az öt elemzett intézményes berendezkedés létrejöttének a részleteit, a vonatkozó törvényes rendelkezések mögött fölfedezhető indítékokat, motivációkat és politikai szándékokat, a vonatkozó törvények időbeni alakulását, illetve a létrejött autonóm szerkezetek kompetenciáit. A kisebbségi választásoknak az elemzés központi elemeként kezelt rendszerét öt remekbe szabott esettanulmány ismerteti, amelyek nagyjából azonos szerkezetü és módszerủ megközelítésben részletezik, a megértéshez szükséges kontextuális elemek jó érzékkel arányított ismertetése mellett, a kisebbségi önkormányzati választások főbb jellemzőit az öt ország vonatkozásában, megfelelően kidomborítva a közös elemeket és a különbségeket.

A tulajdonképpeni összehasonlító elemzés nyolc dimenzió - a szavazásra jogosultak körének a behatárolása és ezzel kapcsolatosan a regisztráció vagy a „listázás" bonyolult problematikája; a csoporttagság objektív és szubjektív kritériumai; a választott testületek legitimitásának a kérdése; a választás érdemi jellege a jelöltállítás, illetve a választási verseny tekintetében; a szavazólap szerkezetével kapcsolatos problémák; a választási részvétellel kapcsolatos tapasztalatok; a választási formula; a választás kimenetelében, eredményeiben tükröződő kontinuitás, illetve ingadozás - szerint realizálódik. Noha ebből a nyolc alfejezetből fontos részletek derülnek ki, egészében véve kritika fogalmazható meg azzal kapcsolatosan, ahogy 
Dobos Balázs megoldja a vállalt feladat lényegét, az elemzés komparatív összetevőjét. Az említett nyolc dimenziót taglaló alfejezetek módszere meglehetősen következetlen: az öt országra vonatkozó részletek bemutatásának a tekintetében a vonalvezetés nem elég biztos kezü, az egyes országokra vonatkozó információk esetlegesek, és az alfejezetek többségére a magyar esettel kapcsolatos adatok túlsúlya jellemző. Egy körültekintően megszerkesztett összehasonlító táblázat minden bizonnyal sokat eloszlatott volna azokból a hiányérzetekből, amellyel az olvasók egy része legalábbis elraktározza magában azt, amivel Dobos Balázs könyve elolvasásának az eredményeképpen gazdagodott.

Dobos Balázs újabb könyve a személyi elvü kisebbségi autonómiáról fontos dokumentuma annak a fejlődésnek, amely a szerző szakmai arcélét egyre határozottabb kontúrral teszi láthatóvá. A figyelmes olvasó számára megismerszik belöle ugyanakkor, hogy minél többet tud Dobos Balázs a személyi elvű kisebbségi autonómiáról, annál nehezebb számára kitérni a kérdés elől, hogy mire jó végső soron a nem területi, kulturális autonómia, ha intézményes megvalósulásának legautentikusabb eseteiből is az szürhető le konklúzióként, hogy több velük a gond, mint a felmutatható eredmény. 